\title{
Konsep Kesempurnaan Tokoh Wong Menak dalam Wayang Sasak
}

\author{
Muh. Syahrul Qodri \\ FKIP Universitas Mataram \\ Jalan Majapahit No. 62 Mataram, Nusa Tenggara Barat \\ Email: arull09@yahoo.co.id
}

\begin{abstract}
The problem discussed in this article is the values of perfection in the main character of Jayengrana in Wong Menak story of Wayang Sasak in its relation to other figures in the puppet. To explore this issue, the analysis method used is Roland Barthes' semiotic perspective. Data were collected from interviews and literature study. After applying the stages of semiotic analysis, which is based on 5 codes of Roland Barthes' semiotics (i. e. hermeneutic, connotation, symbolic, proaretic, and cultural codes), it can be concluded that the perfection of Wong Menak story lies on the glory of himself as wong menak as represented through the his nicknames which prevails on every journey of life. This is because of his ability to manage the five characters that exist in companions and manifest themselves in wong menak itself.
\end{abstract}

Keywords: perfection, wong menak, puppet sasak

\begin{abstract}
ABSTRAK
Masalah yang dibahas dalam artikel ini adalah tentang nilai kesempurnaan yang dimiliki oleh tokoh utama Jayengrana dalam Wong Menak di dalam Wayang Sasak yang dikaitkan dengan tokoh-tokoh lainnya dalam wayang tersebut. Untuk mengupas persoalan tersebut, metode analisis yang digunakan adalah semiotika perspektif Roland Barthes. Data yang dianalisis adalah data dari hasil wawancara dan studi pustaka. Setelah melewati tahapan analisis semiotika yang berlandaskan pada lima kode Roland Barthes (yaitu kode hermeneutik, konotatif, simbolik, proaretik, dan kode kultural), dapat ditarik sebuah kesimpulan bahwa kesempurnaan Wong Menak terletak pada kejayaan dirinya sebagai wong menak yang direpresentasikan lewat nama-nama julukan yang disandangnya, sehingga senantiasa berjaya pada setiap perjalanan kehidupannya. Hal ini disebabkan oleh kemampuannya mengelola kelima karakter yang ada pada diri sahabat-sahabatnya dan menyatu dalam diri wong menak itu sendiri.
\end{abstract}

Kata kunci: kesempurnaan, wong menak, wayang sasak 


\section{PENDAHULUAN}

Bulan terlihat cerah malam itu, membuat langit tampak begitu cerah. Lapangan berumput sudah mulai dipenuhi oleh orang-orang yang siap menonton pertunjukan wayang. Sebuah ranggon ${ }^{1}$ berdiri tegak di ujung lapangan. Kain putihnya sudah memancarkan cahaya dari labakan ${ }^{2}$ yang disulut oleh sang dalang, setelah dilakukan beberapa ritual dengan mantra.

Beberapa saat kemudian, sebuah wayang berbentuk simetris segi lima terlihat bergetar dari balik layar, yang kemudian tertancap kuat. Darmoatmojo (1989: 17) menyatakan bahwa bentuk dasar segi lima tersebut mengandung pengertian lima hal yang sangat didambakan oleh seluruh makhluk hidup di bumi ini, yaitu keselamatan, kebahagiaan, kesejahteraan, keadilan, dan kedamaian. Sementara itu, bentuk keseluruhan gunungan tersebut pada hakikatnya merupakan pengejawantahan jagat raya ini beserta segala isinya secara utuh seperti gunung, laut, tumbuhtumbuhan, binatang, dan juga manusia.

Setelah gunungan itu tertancap, wayang yang muncul selanjutnya adalah seorang tokoh yang berpenampilan sangat sederhana, namun sangat diagungkan serta dikeramatkan. Tokoh ini bernama Jayengrana, dan dinamai dengan banyak nama, yaitu, Wong Agung Menak, Jayeng Palugon, Jayeng Jurit, Jayeng Satru, dan lain-lain.

Pertanyaan yang muncul kemudian adalah, kesempurnaan seperti apakah yang dimiliki oleh Jayengrana sehingga ia dijuluki sedemikian rupa, serta diagungkan dan dikeramatkan? Keagungan seperti apa yang dimilikinya dan bagaimanakah keutamaannya tersebut? Lalu bagaimanakah hubungannya dengan tokoh wayang yang lainnya?

Pertanyaan-pertanyaan tersebut perlu dikaji dengan melibatkan konteks sosial dan historis pemilik wayang ini, yaitu masyarakat Sasak. Hal itu karena wayang merupakan sebuah tradisi Sasak yang bisa dijadikan sebagai salah satu kekayaan budaya lokal, atau biasa disebut sebagai local wisdom atau kearifan lokal. Kearifan lokal merupakan perilaku positif manusia dalam berhubungan dengan alam dan lingkungan sekitarnya, yang dapat bersumber dari nilai agama, adat istiadat, petuah nenek moyang, atau budaya setempat, yang terbangun secara alamiah dalam suatu komunitas masyarakat untuk beradaptasi dengan lingkungan di sekitarnya (Ernawi, 2009:7).

Jika demikian, kearifan yang dimiliki oleh sekelompok masyarakat mestinya memiliki nilai-nilai luhur yang sudah sedemikian rupa diterapkan dalam kehidupan sehari-hari, dan dijadikan sebagai pedoman dalam bersikap, bertutur, dan berperilaku. Begitu juga halnya dengan nilai-nilai yang terkandung di dalam lakon Wong Menak yang akan dibahas dalam tulisan ini. Salah satu nilai yang perlu mendapatkan perhatian adalah nilai kesempurnaan yang dimiliki oleh tokoh utama Wayang Menak, sehingga kesempurnaan tersebut dapat dijadikan sebagai pembelajaran hidup, baik bagi masyarakat Sasak sendiri maupun bagi masyarakat lain.

Berdasarkan uraian di atas, persoalan yang akan dibahas dalam tulisan ini adalah tentang nilai-nilai kesempurnaan yang dimiliki oleh Jayengrana dalam lakon Wong Menak dalam Wayang Sasak yang dikaitkan dengan tokoh-tokoh lainnya dalam wayang tersebut.

\section{Penelitian yang Relevan}

Penelitian-penelitian yang membahas tentang wayang sebenarnya sudah banyak dilakukan, diambil dari berbagai macam sisi, dikaji dari berbagai sudut pandang, dan dianalisis dari berbagai perspektif. Penelitian-penelitian tersebut perlu mendapatkan perhatian untuk terus dikembangkan dan dijadikan sebagai rujukan bagi penelitian selanjutnya, termasuk penelitian ini. 
Penelitian yang berjudul Eksistensi Wayang Golek Langkung di Kota Jepara Sebagai Wujud Pengembangan Budaya Jawa yang dilakukan oleh Siti Khotiah dkk. memberikan gambaran yang detail mengenai wayang golek Langkung yang ada di Kota Jepara, baik itu sejarah asal-usulnya, makna filosofis maupun makna pemberian nama, dan sebagainya, sehingga diharapkan masyarakat Kota Jepara atau kota-kota lainnya dapat belajar banyak dari golek Langkung ini.

Selanjutnya, Mukti (2014) memberikan gambaran cukup rinci mengenai wayang kulit, khususnya pada lakon Cupu Manik Astagina, yang didalangi oleh Enthus Susmono. Penelitian ini menunjukkan relevansi terhadap perbaikan umat dan pelestarian wayang pada umumnya, yang dimulai dari pemahaman tentang bentuk pertunjukan wayang kulit purwa lakon Cupu Manik Astagina dan berusaha memperoleh gambaran tentang ajaran yang disampaikan dalam pertunjukan wayang kulit purwa lakon Dewaruci yang disajikan oleh dalang Enthus Susmono, serta nilai-nilai filosofis yang terkandung di dalamnya. Di samping itu, penelitian ini juga berusaha memahami strategi atau cara penyampaian ajaran filosofis tersebut dalam pertunjukan wayang kulit purwa lakon Cupu Manik Astagina yang disajikan oleh dalang Enthus Susmono.

Sementara itu, penelitian yang berkaitan dengan wayang Sasak adalah penelitian yang dilakukan Hambali (2011) dengan judul Resepsi Penonton Terhadap Wayang Haji Lalu Nasib, Gerung, Lombok Barat. Masalah yang dianalisis terkait dengan resepsi penonton, yaitu bagaimana resepsi penonton terhadap unsur-unsur estetika pewayangan Haji Lalu Nasib dan bagaimana resepsi penonton terhadap nilai-nilai dalam pertunjukan wayang tersebut. Hasil penelitiannya menunjukkan, pertama, unsur-unsur khas yang paling menentukan resepsi penonton menggambarkan bahwa pengaruh tokoh punakawan yang berkarakter humor dalam lakon carangan mendapat resepsi paling banyak. Sedangkan terhadap unsurunsur lainnya, yakni unsur tokoh utama pada cerita utama beserta alurnya, sabet, catur (bahasa), gending (musik), durasi pertunjukan, dan etika kurang diresepsi oleh penonton. Hal tersebut diakibatkan oleh unsur cerita utama yang tidak digarap dengan maksimal, terutama tokoh punakawan versi pakem yang berfungsi menerjemahkan maksud tokoh utama pada penonton; bahasa sulit dipahami, kurangnya pengetahuan penonton tentang pedalangan, dan motivasi penonton dalam pertunjukan. Kedua, terdapat perbedaan sudut pandang resepsi antara golongan tua dan golongan muda. Golongan tua meresepsi lebih mendalam dengan melibatkan pengetahuannya tentang pewayangan (pakem) dan meresepsi negatif hal yang dianggap keluar dari pakem. Penyimpangan dari pakem akan berpengaruh terhadap kualitas dan nilai-nilai dalam pertunjukan wayang. Ketiga, dalam menangkap dan memaknai simbol-simbol dalam pertunjukan wayang tidak maksimal dikonkretkan oleh penonton kalangan muda. Sedangkan golongan tua memiliki kemampuan lebih dalam memaknai arti di balik simbol-simbol tersebut. Keempat, nilai-nilai yang diresepsi penonton berupa nilai etis dan tidak etis.

Wayang Sasak juga menarik perhatian seorang antropolog dari Universitas Hawaii, David D. Harnish. Ia banyak menulis tentang masyarakat Sasak, hingga menerbitkan sebuah buku dengan judul Bridges to the Ancestors, Music, Myth, and Cultural Politics at an Indonnesian Festival (2006). Namun yang menjadi rujukan dalam penelitian ini adalah tulisannya yang dimuat di jurnal Asian Music (Spring, 2003) dengan judul Worlds of Wayang Sasak: Music, Performance, and Negotiations of Religion and Modernity. Dalam tulisan itu, didiskusikan mengenai konteks musik wayang Sasak kini dan masa lalu serta perubahannya. Untuk membahas 
hal itu, ia menggambarkan sekilas tentang isi cerita wayang Sasak, sejarahnya, halhal yang memengaruhinya, proses kerja wayang Sasak, terutama bagaimana musik wayang Sasak. Dalam tulisannya, ia banyak menyoroti tentang pengaruh budaya Jawa dan Bali sehingga menghasilkan bentuk wayang Sasak saat ini. Pengaruh lainnya adalah pengaruh agama dan kebijakan pemerintah, hingga ditemukan saat ini, wayang Sasak menjadi sangat terbatas dan kurang mendapatkan perhatian masyarakatnya sendiri. Semuanya itu dijelaskan secara historis oleh Harnish, sehingga harus memunculkan berbagai sejarah sosial budaya masyarakat Sasak, termasuk sejarah kolonialisme yang terjadi di Indonesia, khususnya yang terjadi di Lombok.

\section{METODE}

Sebagaimana sudah diketahui bahwa semiotika merupakan kajian tentang sistem tanda, di mana antara tanda yang satu dan tanda yang lainnya saling berhubungan. Oleh karena itu, dibutuhkan data yang bersumber dari pertunjukan wayang itu sendiri, diseiramakan dengan Serat Menak sebagai sumber cerita wayang Sasak, lalu diperkuat lagi dengan wawancara dengan dalang dan tokoh masyarakat Sasak yang kompeten dalam bidangnya. Pengumpulan data dalam penelitian ini dilakukan dengan dua cara, yaitu wawancara mendalam dan studi pustaka. Beberapa tokoh yang dijadikan sebagai narasumber antara lain adalah Mamiq Rahmat (dalang), Mamiq Agus Fathurrahman (tokoh Budaya), Mamiq Nurasih (tokoh pedalangan), dan Kiai Ratna (tokoh spiritual).

Analisis data dalam tulisan ini menggunakan metode kualitatif bersifat deskriptif. Metode deskriptif digunakan untuk menggambarkan sifat suatu keadaan yang sementara berjalan pada saat penelitian dilakukan dan memeriksa sebab-sebab dari suatu gejala tertentu (Sevilla, 1993: 71).
Hal ini sesuai dengan yang dikemukakan Nawawi (1993: 73) bahwa metode deskriptif merupakan prosedur pemecahan masalah yang diselidiki dengan menggambarkan keadaan objek penelitian pada saat sekarang berdasarkan fakta yang tampak. Dalam hal ini tidak hanya penyajian data secara diskriptif, tetapi juga dikumpulkan, diolah, dan ditafsirkan.

Metode deskriptif di atas akan dibantu dengan pendekatan semiotika perspektif Roland Barthes, yaitu menentukan leksia dari teks atau data yang sudah ada, untuk kemudian dijadikan sebagai penanda guna menemukan petanda sehingga menghasilkan tanda yang lainnya sebagai sebuah proses signifikasi dari penanda dan petanda sebelumnya. Ketika ia mendapatkan tarikan penanda pada tahap kedua, dihubungkan dengan petandanya, maka akan dihasilkan penanda baru yang memiliki makna konotasi. Pemaknaan yang bersifat konotatif ini berangkat dari lima kode yang diberikan Barthes (1990: 19), yaitu kode hermeneutik, konotatif, simbolik, proaretik, dan kode kultural (genomic).

Proses ini disebut Barthes (dalam Budiman, 2005: 94) sebagai proses signifikasi, di mana tanda-tanda pada tataran pertama pada gilirannya hanya akan menjadi penanda-penanda yang berhubungan pula dengan petanda-petanda pada tataran kedua. Selanjutnya, penanda-penanda pada level kedua tersebut juga akan berhubungan dengan petanda-petanda yang menghasilkan penanda ketiga. Begitu seterusnya, sehingga Barthes (2007: 2-3) menyebut semiologi bukan sebatas suatu perkara (cause); semiologi bukanlah suatu ilmu (science), melainkan sebuah petualangan (adventure).

Dalam bukunya Mitologi, Barthes (2011: 162) menjelaskan proses signifikasi ini seperti dapat dilihat pada bagan 1 .

Pada proses selanjutnya, tanda baru yang dihasilkan tersebut dikaitkan dengan keberadaan tokoh lainnya sehingga meng- 


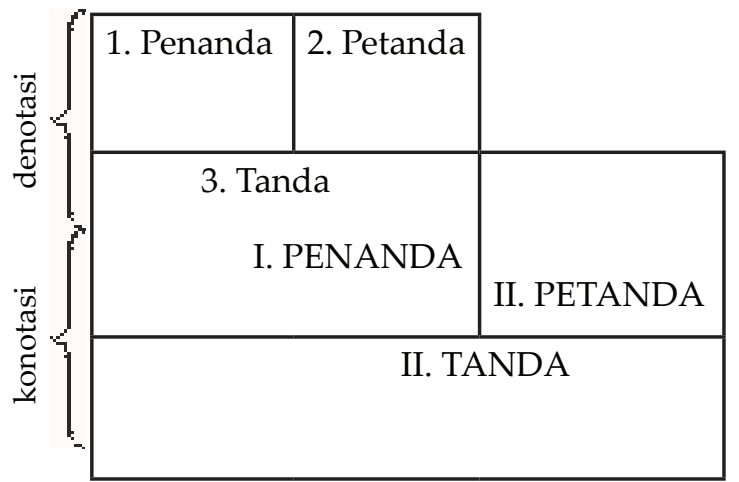

Bagan 1. Proses Signifikasi

(Sumber: Barthes, 2011)

hasilkan penanda baru guna mendapatkan petanda baru berikutnya, lalu menghasilkan signifikasi tingkat berikutnya.

\section{HASIL DAN PEMBAHASAN Deskripsi Data}

Malam itu suasana di daerah Puyung Lombok Tengah terasa agak berbeda dengan hadirnya sebuah pergelaran wayang yang didalangi oleh Mamiq Rahmat dan diprakarsai oleh Tim Peneliti Universitas Mataram. Pergelaran wayang Sasak ini dibantu juga oleh generasi ketiga (G3) keluarga Mamiq Ambawa yang bertepatan dengan perayaan hari bersejarah keluarga tersebut. Momen perayaan ini kemudian dimanfaatkan sebagai wadah melakukan penelitian dan menjadikannya sebagai pengambilan data.

Fragmen cerita "Wong Menak" ini sengaja dipilih untuk menunjukkan kesempurnaan salah satu tokoh yang ada dalam Serat Menak tersebut, yang nantinya dapat dijadikan sebagai contoh dan pembelajaran hidup bagi keluarga generasi ketiga pada khususnya, dan bagi para pemuda Sasak umumnya. Hal ini disebabkan oleh tokoh wayang yang disebut sebagai Wong Menak ini memiliki kesempurnaan yang luar biasa sehingga sebagian besar masyarakat Sasak mengeramatkan tokoh ini. Di samping itu, tokoh Wong Menak adalah sosok yang disegani dan dihormati serta dicintai sebagai pemimpin umat.

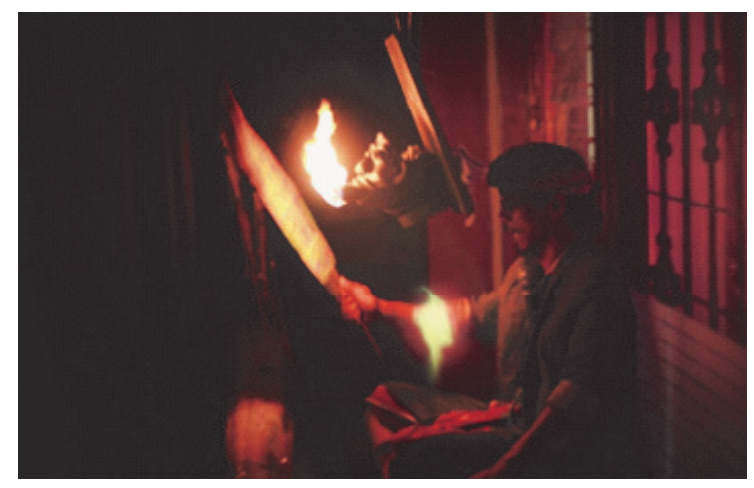

Gambar 1. Dalang Mamiq Rahmat sedang beraksi memainkan wayangnya (Foto: Syahrul Q., 2015)

Dari tokoh ini dapat diambil berbagai macam pembelajaran, sebagaimana yang diungkapkan oleh Cahya (2016: 122) sebagai berikut.

"Pemahaman nilai-nilai simbolik dalam pertunjukan wayang dapat kita lihat dari lakon-lakon wayang dan unsur-unsur pendukungnya yang terbingkai dalam pergelaran wayang yang mengungkapkan keseluruhan kisah kehidupam manusia."

Sejalan dengan pernyataan di atas, perjalanan Wong Menak pada dasarnya adalah perjalanan kehidupan panjang yang dimulai sejak alam ruh, hingga kembali kepada alam ruh yang lain. Artinya, berangkat dari alam rahim, lahir ke dunia tanpa membawa apa pun, lalu tumbuh menjadi anak-anak, remaja, dewasa, hingga kematian menjemput dan ruhnya kembali kepada sang Pencipta.

Tentu saja hal ini akan mengajarkan kepada kita tentang bagaimana menjalani hidup dan kehidupan di dunia ini-yang diharapkan seideal atau sesempurna Wong Menak. Sama halnya dengan yang dilakukan oleh Sunan Kalijaga yang menjadi peletak dasar sinkretisme Jawanisasi Islam yang paling terkemuka telah memanfaatkan seni wayang sebagai alat syiar Islamisasi Jawa (Riyanto, 2018: 8).

Pertanyaannya adalah, siapa sebenarnya sosok yang disebut sebagai Wong Menak ini? Untuk menjawab pertanyaan tersebut, perlu terlebih dahulu mendeskripsikan tokoh Wong Menak sebagai data utama dalam penelitian ini. 


\section{Tokoh Wong Menak}

Sebelum lebih jauh membahas tentang Wong Menak, ada baiknya di sini diungkapkan sekilas perkembangan wayang yang ada di Nusantara. Di antaranya yang menonjol dalam catatan sejarahnya menurut Riyanto (2018: 3-8) adalah:

1. Wayang Kulit Purwa, dengan boneka kulit pipih yang diukir/ditatah dan disungging dengan mengangkat repertoar cerita (pakem balungan) epos besar India Mahabharata (menyajikan kehidupan keturunan wangsa Barata yang diakhiri pengangkatan Parikesit sebagai raja terakhir di Hastinapura paska pertempuran akbar Bharatayuda) dan Ramayana (mengisahkan perjalanan Rama untuk mencari Sinta serta mengalahkan Rahwana dengan bantuan bala tentara kera)

2. Wayang Madya, ciptaan Mangku Negara IV yang berdasarkan karya sastra pujangga besar Ranggawarsita "Pustaka Raja Madya" dengan kisah raja Jayabaya dari Mamenang Kediri yang termasyur dengan kitab ramalan zaman "Jangka Jayabaya"

3. Wayang Gedog dengan boneka kulit yang ditatah dan disungging dengan repertoar cerita jalinan asmara Panji Asmara Bangun dengan Dewi Candra Kirana dari kerajaan Jenggala dan Kediri.

4. Wayang Klithik atau Wayang Krucil dengan boneka dari kayu pipih dan tangantangan dari kulit yang ditatah dan disungging dengan repertoar cerita Damarwulan dan tokoh antagonis Minak Jinggo dari periode zaman Majapahit.

5. Wayang Beber yang berupa gulungan kain yang dilukis dan disungging (digambar) tokoh-tokoh wayang dengan repertoar cerita kisah Panji, yang mirip dengan wayang Gedog.

6. Wayang Golek dengan boneka dari kayu tiga dimensi dengan ditatah, diukir, dan disungging dengan repertoar cerita epos Mahabharata, Ramayana, serta legenda pahlawan Islam Amir Hamzah dengan pu- nakawan-punakawan termasyhurnya Umarmaya dan Umarmadi yang disebut sebagai wayang Menak.

7. Wayang Wong merupakan wayang yang dimainkan oleh manusia (wong berasal dari kata uwong yang berarti orang atau manusia dalam bahasa Jawa).

8. Wayang Topeng merupakan model lain dari wayang orang atau wayang wong di mana pementasannya tidak menggunakan riasan langsung, tetapi menggunakan topeng sebagai gantinya. Wayang yang menggunakan topeng ini disebut sebagai wayang topeng.

9. Wayang Suluh dengan cerita seputar revolusi kemerdekaan Republik Indonesia untuk meningkatkan semangat nasionalisme bagi masyarakat Indonesia

10. Wayang Ukur karya Sukasman merupakan bentuk redesign dari karakter wayang kulit purwa.

Selain jenis atau bentuk wayang di atas, banyak juga jenis wayang lainnya yang mengalami perkembangan pasang surut di wilayah Nusantara, seperti wayang Cina, Kancil, wahyu, bahkan ada yang lebih bersifat modern seperti wayang Pancasila.

Di samping itu, Sunardi, dkk. (2016: 197-202) juga memberikan gambaran perkembangan wayang dengan perspektif yang berbeda, yaitu adanya wayang suluh, wayang Pancasila, Wayang Sadat dan wayang Walisanga, wayang Kampung Sebelah, Wayang Babad Cirebon, Bali, dan Pesisiran, yang kesemuanya masuk dalam kategori wayang babad Nusantara.

Dari kesemua jenis wayang yang disebutkan di atas, masyarakat Sasak tetap mempertahankan wayang yang terbuat dari kulit dengan mengangkat cerita legenda Amir Hamzah dan mempertunjukkan bayangan wayang kepada penonton. Legenda tersebut kemudian diadaptasi sehingga menjadikannya sangat khas Sasak.

Hal ini wajar karena terjadinya persentuhan budaya menuju akulturasi budaya. 
Seperti yang diungkapkan oleh Rusliana (2016: 152).

Adanya akulturasi kebudayaan, adalah peristiwa yang wajar terjadi. Sejarah telah membuktikan bahwa bumi Nusantara dari zaman dulu hingga sekarang banyak didatangi oleh orang asing. Akan tetapi dalam proses persentuhannya ini tidaklah hanya menyerap, mengambil atau memindahkan begitu saja, melainkan secara alami disesuaikan dengan situasi dan kondisi serta kepribadian bangsa Indonesia sendiri, atau senantiasa diselaraskan dengan kebudayaan yang telah ada sebelumnya. Pola kebudayaan Indonesia tetap tidak berubah, sebab anasir kebudayaan asing itu telah dijalin dalam pola kebudayaan Indonesia.

Demikianlah, wayang Sasak menjadi khas dan dimiliki oleh masyarakat Sasak di Pulau Lombok dan kemudian wayang tersebut disakralkan dan dihormati keberadaannya oleh masyarakat pendukungnya. Tokoh Wong Menak menjadi tokoh tauladan yang layak dicontoh dan diikuti jejak perjalanan hidupnya.

Menurut Mamiq Agus Fathurrahman, kata menak berarti utama. Sementara itu, kata wong berarti orang. Oleh karena itu, secara etimologis wong menak dapat diartikan sebagai orang yang utama, atau orang yang memiliki keutamaan. Oleh karena dia adalah orang yang utama, berarti di setiap kesempatan, di setiap waktu, ia selalu menjadi yang utama, dan karena keutamaannya itulah ia dijuluki banyak nama, seperti Jayengrana, Jayeng Palugon, Jayeng Jurit, Jayeng Laga, Jayeng Satru, dan lain-lain. Dari nama-nama inilah nantinya akan ditelusuri jejak-jejak kesempurnaan Wong Menak dalam wayang Sasak.

Pada dasarnya, cerita Wong Menak ini diadopsi dari Serat Menak, yaitu hikayat Amir Hamzah, yang merupakan khasanah kesusastraan Melayu yang bersumber dari Persia, Syah Nameh, dan ditulis dalam bahasa Kawi. Amir Hamzah adalah paman Nabi Muhammad saw. yang dengan heroik ikut membela dan mempertahankan Islam dari gangguan dan serangan musuh-musuh Islam waktu itu. Dalam Serat Menak, Amir Hamzah dan kepahlawanannya itu diangkat menjadi tokoh sentral yang diberikan nama-nama baru, juga gelar-gelar seperti Wong Menak, Baginda Ambyah, Sang Menak Jayengdimurti, dan lain-lain.

Meskipun demikian, sebagaimana kita ketahui bahwa paman Nabi Muhammad saw. bernama Abu Thalib. Di sini muncul pertanyaan, mengapa berubah menjadi Amir Hamzah?

Dalam hal ini, Mamiq Nurasih dari Kidang Lombok Tengah memberikan pendapatnya, bahwa semua itu merupakan simbol-simbol yang perlu dikaji lebih dalam lagi. Tokoh Amir Hamzah yang dijadikan sebagai sentral dalam cerita tersebut, merupakan tokoh yang menyebarkan Islam dan melakukan banyak pertempuran melawan kezaliman dan kekafiran. Ia juga melewati berbagai perjalanan yang sangat panjang, yang dalam perjalanannya itu ia dapat memberikan pembelajaran hidup yang sangat berharga.

Dalam konteks sejarah, paman Nabi Muhammad saw. selalu berusaha melindungi keponakannya, tetapi bukan sebagai penyebar Islam. Artinya, tokoh Amir Hamzah ini tiada lain adalah Rasulullah itu sendiri. Akan tetapi, dalam ajaran Islam tidak boleh merepresentasikan sosok Nabi Muhammad saw. dalam wujud apa pun. Oleh karena itulah, Serat Menak ini tidak langsung menceritakan perjalanan Muhammad saw., tetapi perjalanan Amir Hamzah.

Bahasa yang dipergunakan dalam wayang Sasak adalah bahasa Kawi. Bahasa Kawi dalam hal ini lebih berarti sebagai bahasa yang lazim dipergunakan dalam kesusastraan pada zaman dulu, bukan berarti bahasa Kawi menjadi bahasa keseharian masyarakat Sasak. Meski menggunakan bahasa Kawi yang identik dengan Jawa Kuno, tetapi pada prisnsipnya wayang Sasak me- 


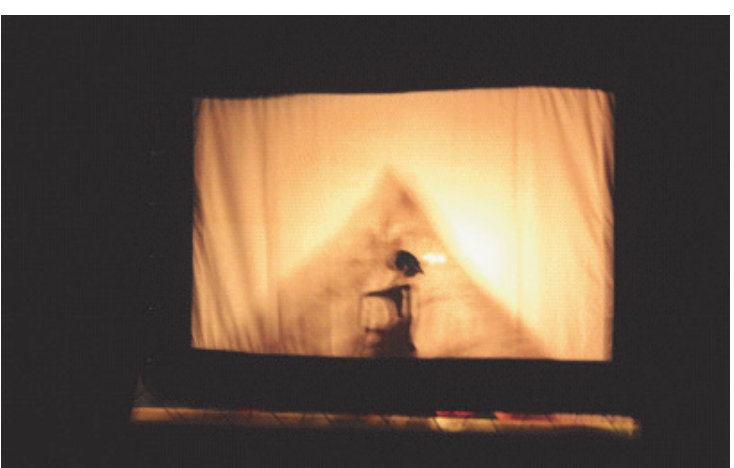

Gambar 2 Tokoh Wong Menak pada saat awal kemunculannya (Foto: Syahrul Q., 2015)

miliki perbedaan yang signifikan dengan wayang Jawa, karena sumber ceritanya pun berbeda.

Kembali kepada tokoh Wong Menak, ia digambarkan sebagai orang yang berpenampilan sangat sederhana, tanpa banyak pernak-pernik yang menghiasi tubuhnya, dan tanpa perhiasan seperti gambaran seorang raja pada umumnya. Ia diceritakan sebagai pemimpin yang sangat disegani, baik oleh kawan maupun lawan karena memiliki welas asih dan kesaktian yang luar biasa. Hal ini menyebabkan ia sangat dihormati dan dicintai oleh rakyatnya, dan ada kebanggaan tersendiri memiliki sosok pemimpin yang berkarakter seperti itu, yang saat ini sudah sangat langka ditemukan di muka bumi ini.

Untuk diketahui bahwa dalam masyarakat Sasak dikenal dua tingkatan strata sosial, yaitu kalangan bangsawan dan kalangan biasa. Kalangan bangsawan ini disebut juga sebagai orang menak. Entah apakah ada hubungannya dengan julukan ini, namun Mamiq Agus Fathurrahman memberikan penjelasan yang masuk akal. Ia mengatakan bahwa semestinya, yang dianggap sebagai orang menak itu adalah orang yang menyerupai atau selaras dengan tokoh Wong Menak di dalam Wayang Sasak. Artinya, seseorang yang masuk dalam kategori bangsawan adalah tiada lain karena memiliki sifat-sifat yang dimiliki tokoh Wong Menak. Pada tataran realitasnya, orang yang dianggap bangsawan hanya sebatas karena berasal dari keturunan tertentu, bukan karena sikap dan perilakunya.

Dari sini kemudian Wong Menak mendapatkan berbagai julukan dan menjadi tokoh yang disakralkan. Berikut ini, akan dikemukakan nama-nama julukan Wong Menak dan penjelasan mengapa nama itu melekat pada karakternya, namun dalam tulisan ini akan dipaparkan lima julukan saja, yaitu Jayengrana, Jayeng Palugon, Jayeng Satru, Jayeng Jurit, dan Jayeng Palupi (Depdikbud, 1993: 73).

Di samping nama-nama julukan di atas, data lain yang sangat penting yang berkaitan dengan kesempurnaan Wong Menak adalah, ia memiliki beberapa sahabat dekat dan setia, yaitu Umar Maya, Maktal, Umar Madi, Alam Daur, dan saudara kembar Taptanus dan Santanus. Keenam sahabatnya inilah yang senantiasa mendampingi Wong Menak dalam berbagai peristiwa dan urusan kerajaan. Sahabat-sahabatnya ini menjadi penting karena setiap tokoh tersebut memiliki nilai simbolis yang sangat kental dengan sikap dan karakter Wong Menak itu sendiri. Beberapa tokoh dalam wayang yang merupakan sahabat terdekat dari Wong Menak menjadi penting untuk dibahas, karena memiliki keterkaitan yang sangat erat dengan simbol-simbol kesempurnaan Wong Menak (Depdikbud, 1993: 74-77).

\section{Hasil Analisis}

Sebagaimana disebutkan di atas, bahwa analisis makna yang dilakukan pada tokoh Wong Menak melalui proses signifikasi, dengan melihat julukan-julukan tokoh tersebut dan diderivasi sedemikian rupa, sehingga mendapatkan hasil sebagai berikut.

1. Jayengrana

Dalam bahasa Kawi, kata Jayengrana terdiri dari dua kata, yaitu jayahing dan rana. Jayahing ini kemudian mengalami proses peleburan fonem, atau dalam istilah 
linguistik disebut sebagai proses monoftongisasi. Dalam proses monoftongisasi pada bahasa Kawi, yaitu bunyi " $i$ " bertemu dengan bunyi "a", akan berubah menjadi "e", sehingga kata jayahing berubah menjadi jayeng, yang sama-sama berarti jaya. Sementara itu, kata rana itu sendiri berarti diri.

Setelah melalui proses analisis semiotis, jayengrana dapat diartikan sebagai keutamaan diri, atau diri yang utama. Keutamaan diri ini tentu saja harus diperoleh melalui berbagai macam proses perjalanan hidup yang tidak mudah. Ia harus mampu menaklukkan begitu banyak musuh, dan musuh yang paling berat adalah diri sendiri. Kemampuan menaklukkan atau mengendalikan diri sendiri inilah yang menyebabkan sosok tersebut dapat dijuluki sebagai jayengrana.

\section{Jayeng Palugon}

Jayeng berarti jaya, sebagaimana dijelaskan pada poin sebelumnya, sedangkan kata palugon atau palagan sebenarnya memiliki arti laga. Wong Menak dijuluki sebagai Jayeng Palugon karena ketika ia berlaga di medan tempur, dia selalu menjadi yang utama. Dalam pertempuran atau berlaga, Wong Menak senantiasa lebih menonjolkan sisi kemanusiaan daripada kekerasan akan peperangan itu sendiri. Pada hakikatnya, hal ini mengindikasikan bahwa peperangan yang sebenarnya adalah melawan diri sendiri, sehingga Jayeng Palugon dapat berarti jaya dalam menaklukkan diri sendiri.

Bercermin dari tokoh yang dijuluki $J a-$ yeng Palugon, sosok Wong Menak adalah seorang yang berjaya di setiap medan laga, adalah sosok yang berani melawan siapa saja, terutama dalam hal membela kebenaran. Dengan demikian, wong menak pada hakikatnya adalah seorang yang memiliki tanggung jawab besar dalam membela kebenaran. Tidak semua orang dapat melakukan hal itu, ketika kebenaran disembunyikan dalam peti kekuasaan, ditenggelamkan dalam lautan fitnah, atau dikubur dalam kegelapan jiwa, banyak orang takut untuk sekadar bersuara, apalagi melawan. Di sinilah letak keutamaan sosok yang disebut sebagai Wong Menak.

\section{Jayeng Satru}

Kata satru berarti pimpinan dalam peperangan. Dalam setiap peperangan, tokoh Wong Menak senantiasa menjadi yang utama dalam menyusun strategi, merangkai kegiatan, serta melancarkan serangan. Oleh karena itu, jayeng satru dapat diartikan sebagai orang yang memiliki keutamaan tertinggi dalam memimpin sebuah peperangan. Penanda ini pada hakikatnya adalah berarti dapat mengendalikan diri sendiri dalam setiap perilaku, sehingga sebagai sosok Wong Menak semestinya dapat mengendalikan diri sendiri.

Berangkat dari kata satru, Jayeng Satru adalah seorang yang berjaya dalam medan pertempuran. Untuk mencapai hal itu, bukan hanya membutuhkan kekuatan secara fisik semata, melainkan membutuhkan kecerdasan dalam menyusun strategi, sehingga perang bisa dimenangkan dengan sempurna.

Perlu digarisbawahi bahwa dalam setiap peperangan yang dijalankan bukan semata persoalan kalah-menang, atau bunuhmembunuh, tetapi lebih pada tujuan yang ingin dicapai, yaitu kebenaran itu sendiri yang berlandaskan pada nilai kemanusiaan. Untuk mencapai itu, dibutuhkan perenungan dan pemikiran yang mendalam dalam mengendalikan setiap pertempuran. Dengan demikian, Jayeng Satru bisa dikatakan sebagai sosok yang mampu mengendalikan pertempuran.

\section{Jayeng Jurit}

Jurit bisa diartikan sebagai perjalanan. Dengan demikian, jayeng jurit berarti kejayaan dalam perjalanan. Tokoh Wong Menak dalam cerita Serat Menak ini dikisahkan melewati berbagai macam perjalanan, melewati hutan belantara, lautan samudera, gunung dan lembah, dan sebagainya. Akan tetapi pada hakikatnya, semua per- 
jalanan itu merupakan simbolisasi dari perjalanan hidup dari tokoh tersebut, betapa beratnya menjalani kehidupan dengan berbagai rintangan dan cobaan, dan tokoh Wong Menak mampu melewati itu semua, sehingga layak dijuluki sebagai $J a-$ yeng Jurit. Penanda ini pada dasarnya juga berarti bahwa perjalanan yang dimaksudkan adalah kehidupan itu sendiri, sehingga setelah mampu mengalahkan diri sendiri, mengendalikan diri sendiri, kita akan terus berjalan menyusuri kehidupan yang penuh dengan ujian ini.

\section{Jayeng Palupi}

Palupi sebenarnya dalam bahasa Jawa Kuno berarti tenang dan selalu dikenang. Ada juga yang mendefinisikannya sebagai kehidupan, sehingga jayeng palupi bisa berarti jaya dalam kehidupan atau kejayaan yang tenang dalam menjalani kehidupan. Setelah melalui proses semiologis, dapat ditarik suatu makna konotatif bahwa Jayeng Palupi sebenarnya memiliki arti sosok yang tenang. Ketenangan ini dapat diraih karena ia memperjuangkan kebenaran, meski melewati berbagai peperangan atau cobaan, serta perjalanan hidup yang penuh dengan ujian.

Dari penjelasan di atas dapat dijelaskan bahwa sosok Wong Menak pada hakikatnya adalah menjadi sosok yang berperang membela kebenaran, melawan diri sendiri, menaklukkannya, serta mengendalikannya, sehingga mendapatkan ketenangan dalam kehidupan ini.

Di samping itu, dalam melihat kesempurnaan Wong Menak, perlu juga disinkronkan dengan para sahabatnya yang selalu mengikuti perjalanannya. Di bawah adalah nama-nama para sahabat Wong Menak berikut makna yang tersirat yang dibawanya.

\section{Para Sahabat Wong Menak}

1. Umar Maya

Tokoh ini adalah putra Tambi Jumiril dari Talkandangan. Ibunya bernama Siti
Mahya, saudara tertua dari Abdul Mutalib (ayah Jayengrana). Dalam pewayangan Sasak, tokoh ini digambarkan bertubuh gendut pendek, perut buncit, hidung bulat besar, dan bergigi hanya sebuah pada rahang atas. Bentuk keseluruhan dari tokoh ini sangat karikatural. Kendatipun demikian, tokoh ini memiliki sifat yang sangat baik, arif bijaksana, dan banyak memiliki keahlian, di antaranya bisa terbang, bisa mengobati berbagai macam penyakit, bisa menghilang, dan mampu berdiri di atas lempengan besi dengan ujung jarinya. Kebijaksanaan yang dimilikinya ini senantiasa dibutuhkan oleh Jayengrana, karena Umar Maya adalah tokoh yang sangat cerdas dan memiliki tingkat intelektual yang tinggi. Oleh karena itulah ia selalu mendampingi Jayengrana dalam setiap perjalanannya.

Sebagaimana yang sudah dijelaskan di atas, Umar Maya adalah sosok sahabat yang setia terhadap Wong Menak. Kecerdasan yang dimilikinya membuatnya menjadi begitu penting dalam perjalanan kisah Wong Menak. Dengan demikian, sebagai seorang yang menak, seorang yang utama, semestinya memiliki kecerdasan intelektualistas yang tinggi sehingga menjadikannya bijak dalam mengambil setiap keputusan. Ini menjadi penting karena dalam kehidupan sehari-hari, sebagai manusia harus belajar dan memiliki kecerdasan dalam menghadapi berbagai macam persoalan kehidupan.

\section{Maktal}

Tokoh ini adalah putra Raja Absan bin Pandita Maskun dari Albania. Sifatnya begitu tenang, tawakal, dan sangat setia kepada Wong Menak, sehingga diakui sebagai saudara oleh Wong Menak sendiri. Ketenangan yang dimilikinya ini berasal dari ketaatan dan kepatuhannya dalam menjalankan berbagai tugas yang diembannya, terutama dalam menjalankan perintah dari sang Pencipta. Pada hakikatnya, ketika seseorang melakukan hal yang benar sesuai dengan norma hukum yang berlaku, maka 
hidupnya akan tenang, tanpa beban derita. Beban derita yang dialami seseorang biasanya datang karena ulah dirinya sendiri.

Dalam kehidupan sehari-hari, seseorang yang berjalan dalam kebenaran memang akan tenang hidupnya, tanpa dibebani oleh rasa bersalah ataupun ketakutan. Kehidupan yang seperti itu, direpresentasikan melalui tokoh Maktal ini.

\section{Umar Madi}

Tokoh ini digambarkan dalam bentuk berbadan gemuk, perut buncit, bermata sipit, bergigi hanya sebuah pada rahang atas. Ia adalah putra sulung raja Kohkarib yang bernama Umar Ikrab. Jumlah saudaranya sebanyak 44 orang, dan dialah yang paling jelek wajahnya. Di samping itu, dia juga sangat kuat makan, rakus, memiliki kemauan yang sangat banyak. Meski demikian, ia adalah pengikut Wong Menak yang sangat setia.

Tokoh Umar Madi adalah representasi dari manusia pada umumnya, yang kebanyakan rakus dan memiliki banyak keinginan. Ini sebenarnya melambangkan bahwa manusia memiliki nafsu yang senantiasa memengaruhinya untuk ke arah hal yang negatif.

Meskipun digambarkan begitu negatif, tokoh ini menjadi sangat penting karena pada hakikatnya setiap manusia memiliki sisi gelap dalam dirinya, namun bukan berarti harus merusak segalanya, melainkan menjadi ujian bagi manusia untuk bisa mengendalikan diri. Itulah salah satu alasan, mengapa setiap tahun umat muslim di seluruh dunia diwajibkan berpuasa, yaitu untuk mengendalikan hawa nafsu. Tokoh Umar Madi sebenarnya merupakan simbol dari hawa nafsu diri manusia.

\section{Alam Daur}

Tokoh ini disebut juga sebagai Selandir atau Serandil. Ia adalah putra dari Prabu Sadalsah, raja Sailan, dan ibunya bernama Basirin binti Syeh Bakar Abu Meswan, tetesan darah dari Nabi Idris dari pihak perempuan. Ia dilukiskan sebagai manusia yang bertubuh tinggi besar, gampang marah, dan tak kenal ampun, sehingga paling ditakuti oleh musuh. Ia bersenjatakan gada yang sangat besar dan menunjukkan kekuatan dan keperkasaannya dalam bertempur. Alam Daur pada hakikatnya melambangkan kekuatan dan amarah yang membara.

Dalam keadaan tertentu, seseorang perlu bertindak tegas, keras, tapi jelas arah dan tujuannya. Apalagi dalam keadaan terdesak, terjepit, atau terspojok. Seseorang harus melawan. Seperti yang pernah diungkapkan oleh Soekarno dalam pidatonya,

“... tiap makhluk, tiap umat, tiap bangsa, tidak boleh tidak, pasti akhirnya bangkit! Pasti akhirnya bangun! Pasti akhirnya menggerakkan tenaganya. Jangan lagi manusia, jangan lagi bangsa, walau cacing pun, tentu bergerak berkeluget-keluget kalau merasakan sakit!".

Seperti itulah sosok Alam Daur, atau sering disebut sebagai Selandir. Ia akan mengamuk pada saatnya, menyerang musuhnya dengan keras, sehingga tidak akan ada yang bisa melawannya. Kekuatannya yang luar biasa, dibarengi dengan gadanya yang besar, membuatnya menjadi sosok yang paling mengerikan bagi musuh. Oleh karena itulah, tokoh ini kerap dijadikan sebagai sosok yang paling dikagumi dan dijadikan sebagai inspirasi oleh kebanyakan masyarakat Sasak, yaitu mampu menggugah semangat juang. Bahkan bagi kalangan tertentu, diciptakan jimat atau benda keramat dengan menggunakan namanya, Selandir.

5. Saudara Kembar Taptanus dan Santanus

Tokoh yang kelima adalah kesatuan dan keterpaduan antara Taptanus dan Santanus, dua orang bersaudara kembar yang selalu bersamaan dan sangat setia kepada Wong Menak. Kedua tokoh ini secara harfiah melambangkan dua anggota tubuh 
yang selalu berpasangan, sebagaimana halnya dalam kehidupan nyata bahwa segala sesuatu di dunia ini berpasang-pasangan, seperti atas-bawah, kiri-kanan, luar-dalam, jahat-baik, hitam-putih, bumi-langit, dan sebagainya. Pasangan-pasangan itu pada hakikatnya menunjukkan konsep keseimbangan alam semesta.

Sebagai Wong Menak, keseimbangan diri menjadi sangat penting mengingat situasi dan kondisi kehidupan yang selalu berubah. Adakalanya kita harus lembut dalam menghadapi suatu hal, tetapi kadang membutuhkan kekerasan dalam menaklukannya. Di sisi lain, kadang kita harus berpikir seribu kali sebelum melakukan suatu hal, namun terkadang ada kalanya harus bergerak cepat tanpa berpikir melainkan lebih menggunakan perasaan.

Mencermati hasil proses semiotik pada nama-nama julukan Wong Menak, dapat ditarik garis benang merah yang sebenarnya berhubungan satu sama lain, yaitu pada kata wong menak. Dari sini kemudian melahirkan makna-makna baru yang bersumber dari nama-nama julukan tersebut, sehingga mendapatkan beberapa penjelasan makna, antara lain adalah:

1. Berkaca dari tokoh Jayengrana, setiap orang memiliki kewajiban untuk dapat merealisasikannya, mengendalikan dirinya, dan menjadikan dirinya sebagai orang yang utama dalam hal tersebut, sehingga seseorang tersebut layak disebut sebagai wong menak. Inilah tokoh sentral dan dijadikan sebagai panutan. Atau dengan kata lain, idealnya seorang manusia adalah seperti tokoh Wong Menak ini.

2. Jayeng Palugon pada hakikatnya adalah seorang yang memiliki tanggung jawab besar dalam membela kebenaran. Meski dalam setiap pertempuran, pertentangan dalam hidup, perbedaan cara pandang, hal yang diutamakan bukanlah kalah dan menang, tetapi kebenenaran itu sendiri.
3. Jayeng Satru bisa dikatakan sebagai sosok yang mampu mengendalikan pertempuran. Mengacu kepada point sebelumnya, jika orientasinya adalah kebenaran, maka secara otomatis kita akan dapat mengendalikan pertempuran. Pada kehidupan realitas masa kini, banyak terdapat pertentangan dan pertempuran yang umumnya disebabkan perbedaan pandangan politik. Di sinilah perlu adanya pengendalian diri untuk kembali kepada hal yang benar, bukan semata-mata atas kepentingan golongan tertentu.

4. Jayeng Jurit adalah sosok yang mampu memimpin dan membawa umatnya ke arah jalan yang benar. Dalam kehidupan realitas saat ini, menjadi seorang pemimpin ada baiknya berkaca kepada Jayeng Jurit, agar mampu membawa rakyatnya ke arah yang semestinya.

5. Jayeng Palupi adalah orang yang mampu memiliki ketenangan hidup dan membawa perdamaian bagi kehidupan manusia. Jika point 1 hingga 4 di atas dijalankan dengan baik, kehidupan ini akan terasa damai dan tenang.

Kelima poin di atas adalah satu kesatuan yang utuh. Apabila dari semua makna konotatif tersebut dirangkaikan menjadi satu kesatuan, akan dihasilkan makna baru, yaitu bahwa Wong Menak adalah sosok yang memiliki kemampuan dalam memimpin sekaligus mengendalikan pertempuran sehingga tercipta adanya kedamaian, baik bagi diri sendiri maupun bagi orang lain. Sebagai seorang pemimpin, semestinya mampu membawa umatnya ke arah jalan kebenaran dengan berupaya mengendalikan diri sendiri, karena perang terbesar manusia adalah ketika ia melawan diri sendiri. Di situlah kita akan menemukan ketenangan.

Sementara itu, mencermati karakter para sahabatnya, bisa juga ditarik sebuah garis penghubung antara mereka dan dijadikan sebagai satu kesatuan yang utuh. Dari sini kemudian dilahirkan makna- 
makna baru yang bersumber dari karakterkarakter para sahabat tersebut, sehingga mendapatkan beberapa penjelasan makna, antara lain:

1. Umar Maya, adalah orang yang memiliki kecerdasan intelektual yang tinggi sehingga membentuknya menjadi seorang yang bijaksana;

2. Maktal, adalah orang yang sangat tenang dan taat serta setia kepada kebenaran;

3. Umar Madi, adalah orang yang paling kuat makan, bisa dikatakan rakus, tetapi ia setia kepada Wong Menak;

4. Alam Daur, orang yang memiliki kekuatan yang besar, gampang marah, dan suka mengamuk yang membuat musuhnya menjadi takut;

5. Saudara kembar Taptanus dan Santanus, merupakan simbol keseimbangan yang merupakan konsep alam semesta.

Dari kelima karakter sahabat itu, bisa ditarik satu garis yang menghubungkan karakter mereka, yaitu kata wong menak. Menjadi wong menak harusnya dilengkapi dengan kelima karakter itu, yaitu memiliki kecerdasan intelektual yang tinggi sehingga membentuknya menjadi seorang yang bijaksana; bersifat tenang, taat serta setia kepada kebenaran, harus mampu melawan hawa nafsu; memiliki kekuatan besar dan harus marah pada waktu dan tempatnya; dan yang terakhir adalah memiliki keseimbangan diri dari keempat karakter sebelumnya. Artinya, kelima karakter sahabat Wong Menak itu pada hakikatnya adalah representasi dari kata wong menak itu sendiri.

Lebih jauh lagi, dalam hal ini Mamiq Agus dalam wawancara menegaskan bahwa dalam diri kita, sebenarnya, kita-lah wong menak itu, masing-masing diri, yang kadang pemarah, yang kadang kuat, kadang bernaf$\mathrm{su}$, tetapi harus tetap berada dalam konsep keseimbangan, dan dikumpulkan menjadi satu kesatuan dalam diri (Jayengrana). Jika mampu mengelola kelima karakter tersebut menjadi satu kekuatan bagi diri, itulah yang melahirkan kejayaan-kejayaan yang dalam nama tersebut disebut sebagai Jayahing, Jayeng. Bahkan, jika kita adalah seseorang yang memiliki dan mengusung ilmu pengetahuan sehingga menjadikan kita orang yang utama dalam bidang keilmuan, bisa disebut sebagai Jayeng Ilmu.

\section{SIMPULAN}

Dari dua deskripsi hasil analisis di atas dapat ditarik sebuah simpulan bahwa kesempurnaan Wong Menak direpresentasikan lewat nama-nama julukan yang disandangnya, sehingga senantiasa berjaya pada setiap perjalanan kehidupannya. Hal ini disebabkan oleh kemampuannya mengelola kelima karakter yang ada pada diri sahabat-sahabatnya dan menyatu dalam diri Wong Menak itu sendiri.

Berdasarkan simpulan yang telah disajikan di atas, ada beberapa saran yang diajukan sebagai penutup tulisan ini, antara lain:

1. Masyarakat Sasak sebaiknya memberikan apresiasi tinggi terhadap kelestarian budaya secara umum, khususnya pada wayang Wong Menak sebagai kekayaan budaya masyarakat Sasak;

2. Pemerintah daerah propinsi maupun kabupaten/kota sekiranya dapat memberikan wadah bagi dalang untuk menyuguhkan wayang Sasak sebagai khasanah kearifan lokal masyarakat Sasak;

3. Para akademisi seharusnya sudah mulai memberikan perhatian kepada halhal yang bernuansa tradisi dan memberikan publikasi ilmiah mengenai kekayaan budaya lokal.

\section{Catatan Akhir}

${ }^{1}$ Sebuah panggung kecil sebagai tempat pergelaran wayang.

${ }^{2}$ Lampu untuk pencahayaan wayang.

\section{Daftar Pustaka}

Barthes, R. (1990). S/Z. Diterjemahkan oleh Richard Miller dari S/Z. Oxford: Basil Blackwell Ltd. 
(2007). L'aventure Sémi ologique diterjemahkan oleh Stephanus Aswa Herwinarko. Petualangan Semiologi. Yogyakarta: Pustaka Pelajar.

-----------. (2011). Mythologies diterjemahkan dari oleh Nurhadi dan A. Sihabul Millah. Mitologi. Yogyakarta: Kreasi Wacana.

Riyanto, B. \& Mataram. S. (2018). Perkembangan Wayang Alternatif di Bawah Hegemoni Wayang Kulit Purwa. Panggung, 28 (1), $1-15$.

Cahya. (2016). Nilai, Makna, dan Simbol dalam Pertunjukan Wayang Golek sebagai Representasi Media Pendidikan Budi Pekerti. Panggung, 26 (2), 117- 127.

Darmoatmojo, S. (1989). Gunungan dan Studi Lingkungan Hidup. Gatra, 22/IV.

Depdikbud NTB. (1993). Deskripsi Wayang Kulit Sasak Daerah Nusa Tenggara Barat, Proyek Pembinaan Kesenian Nusa Tenggara Barat 1992/1993.

Harnish, D. D. (2003). Worlds of Wayang Sasak: Music, Performance, and Negotiations of Religion and Modernity. Asian Music, 34 (2), 91-120.

Nawawi, H. (1993). Metode Penelitian Sosial. Yogyakarta: Gajah Mada Press.

Ernawi, I. S. (2009). Kearifan Lokal dalam Perspektif Penataan Ruang, dalam Kearifan Lokal dalam Perencanaan dan Perancangan Kota. Malang: Group Konservasi Arsitektur dan Kota.
Rusliana, I. (2016). Wayang dalam Tari Sunda Gaya Priangan. Panggung, 26 (2), $151-165$.

Budiman, K. (2005). Ikonisitas. Yogyakarta: Buku Baik.

Hambali, M. (2011). Resepsi Penonton Terhadap Wayang Haji Lalu Nasib, Gerung, Lombok Barat. Tesis S2. Program Pascasarjana Universitas Negeri Malang.

Mukti, M. (2014). Pertunjukan Wayang Kulit Purwa Lakon Cupu Manik Astagina Sajian "Dalang Enthus Susmono dalam Pandangan Tabligh: Relevansinya terhadap Usaha Perbaikan Umat dan Pedan Pelestarian Wayang". Laporan Penelitian. Program Pascasarjana Universitas Negeri Yogyakarta.

Sevilla, C. G. (1993). An Introduction to Research Methods diterjemahkan oleh Alimuddin Tuwu. Pengantar Metodologi Penelitian. Jakarta: Universitas Indonesia Press.

Siti Khotiah, dkk. (2013). Eksistensi Wayang Golek Langkung di Kota Jepara sebagai Wujud Pengembangan Budaya Jawa. Laporan Penelitian. Hibah Bersaing DP3M Dikti Kemedikbud.

Sunardi, N. S. K. (2016). Pertunjukan Wayang Babad Nusantara: Wahana Pengajaran Nilai Kebangsaan bagi Generasi Muda. Panggung, 26 (2), 195-207. 